\title{
Hjernen og følelser - fra barn til voksen
}

\author{
Sammendrag \\ Bakgrunn. Moderne nevrovitenskap \\ knytter menneskers atferd, følelser \\ og tanker til nevrobiologiske prosesser \\ i hjernen. Bedre kunnskap om slike \\ sammenhenger kan øke forståelsen \\ for emosjonelle reguleringsproblemer \\ hos barn og ungdom og utvikling av \\ psykopatologi i noen tilfeller.
}

Materiale og metode. Artikkelen er basert på et ikke-systematisk litteratursøk i PubMed og artikler fra forfatternes egne databaser.

Resultater. Flere prosesser danner det biologiske grunnlaget for barn og unges regulering av emosjoner i samspill med sine omgivelser: Lineær utvikling av hvit substans, vekst og etterfølgende eliminasjon av grå substans samt modningen av de ulike nettverk i hjernen. Utvikling av emosjonsregulering hos barn og unge skjer diskontinuerlig, og ulik modningsgrad av involverte nettverk i hjernen kan bidra til å forklare ulike atferdstrekk som er typisk for spesifikke aldersperioder.

Fortolkning. Emosjonsregulering dannes $i$ et komplekst samspill mellom barnets relasjoner, erfaringer og handlinger og dets biologiske og genetiske egenskaper. Å kjenne til det biologiske grunnlaget kan hjelpe til bedre å forstå typiske atferdstrekk ved ulike alderstrinn og barn som har problemer med å regulere sine følelser. Å kartlegge spesifikke genetiske eller miljømessige faktorer som kan hjelpe barn og unge til å håndtere egne følelser, kan også være viktig for å utvikle terapiformer som fremmer tilstrekkelig emosjonsregulering.

\section{Kerstin J. Plessen}

kerstin.plessen@rbup.uib.no

Avdeling for biologisk og medisinsk psykologi

Det psykologiske fakultet

Universitetet i Bergen

Jonas Lies vei 91

5009 Bergen

Divisjon psykiatri

Haukeland universitetssykehus og

Institutt for klinisk medisin

Det medisinsk-odontologiske fakultet Universitetet i Bergen

\section{Galina Kabicheva}

Avdeling for biologisk og medisinsk psykologi Universitetet i Bergen

Barn og ungdoms evne til å regulere sine følelser er avgjørende for god mental helse. Problemer med å regulere følelser er blitt beskrevet særlig hos pasienter med affektive lidelser og angstlidelser. Barn med $\mathrm{AD} / \mathrm{HD}$ (attention-deficit/hyperactivity disorder) eller med atferdsforstyrrelser har imidlertid ofte også vansker med å kontrollere følelsene sine (1). Økt viten om slike tilleggsproblemer kan få betydning for behandlingstilbudet $i$ barne- og ungdomspsykiatrien og utvikling av terapiprogrammer og forebyggende tiltak som sikter inn mot å forbedre emosjonell regulering. Flere terapiformer har som mål å styrke barnets evne til å regulere følelsene, slik som psykodynamisk psykoterapi eller kognitiv terapeutisk tilnærming. Andre intervensjonsprogrammer fremmer positive relasjoner mellom barn og foreldrene, for eksempel «De utrolige årene», en etter hvert godt implementert terapiform som fokuserer på samhandling mellom foreldre og barna (2). På sikt kan det også være aktuelt å utvikle terapiprogrammer som mer direkte behandler nevrobiologiske forhold som ligger til grunn for problemer med emosjonsregulering. Et eksempel på en slik tilnærming er nevrofeedback, som allerede brukes til behandling av AD/HD-symptomer, men ennå ikke direkte til forbedring av emosjonsregulering (3).

Vi ønsker derfor å oppsummere viktige trekk ved barn og ungdoms hjerneutvikling i forhold til utvikling av emosjonsregulering.

\section{Materiale og metode}

Artikkelen er basert på et ikke-systematisk litteratursøk i PubMed i tillegg til artikler fra forfatternes egne databaser, samlet gjennom flere års forskning.

\section{Utvikling av emosjonsregulering}

Emosjonsregulering kan defineres som evnen til å regulere intensitet, latens, frekvens og varighet av emosjonelle uttrykk i henhold til situasjonen $(4,5)$. Reguleringen kan beskrives både som en dynamisk interaksjon mellom ubevisste prosesser (følelsesgenerering som tilskrives limbiske regioner i hjernen) og kognitiv kontroll av følelser (hovedsakelig lokalisert i frontal og prefrontal cortex) $(6,7)$. Regulering av følelser foregår som regel ubevisst, særlig hos mindre barn. Sosiale regler og forventninger (6), eller risiko og belønning (8) kan derimot føre til en bevisst regulering av emosjoner $(9,10)$. Forskningslitteraturen skiller mellom en ytre form for emosjonsregulering (f.eks. når foreldre hjelper et barn til å regulere følelser) og en indre form, som barnet selv opparbeider seg gjennom barndommen. Prosessen er imidlertid ikke avsluttet på et bestemt tidspunkt, og også voksne i krise kan til tider være avhengig av ytre hjelp til å regulere følelser (11).

Begrepet «emosjon» defineres på mange ulike måter. Fagfolk er enige om at emosjoner kommer til kroppslig uttrykk oftere enn andre mentale tilstander. Emosjoner kan variere i intensitet (arousal) og kan ha både positiv og negativ ladning (valence) (12). Det diskuteres om ulike emosjoner er kvalitativt forskjellige og dermed involverer spesifikke regioner i hjernen, eller om forskjellige opplevelser knyttet til de ulike følelsene kan forklares ut fra ulikhetene $\mathrm{i}$ intensitet og positiv eller negativ farging (13).

Emosjonsregulering utvikles diskontinuerlig fra fødsel til ung voksen alder (6, 14). Individuelle forskjeller i evnen til å regulere følelser har stor betydning for barn

\section{Hovedbudskap}

- Emosjonsregulering utvikles gradvis og diskontinuerlig

- Samspillet mellom emosjonelle og kognitive nevrale nettverk er avgjørende for adekvat emosjonsregulering

- Å identifisere faktorer som fremmer en positiv utvikling av emosjonsregulering hos barn med psykiske problemer kan være viktig for behandling 
og unges utvikling $(10,15)$. Nedsatt emosjonsregulering kan føre til impulsiv- og risikoatferd (6), aggresjon (16) og angst (17).

Angst (18) og depresjon (19) er to tilstander der barn opplagt har problemer med emosjonell regulering (henholdsvis regulering av angst og av affekt). Dette sier imidlertid ikke noe om en underliggende årsak. For eksempel kan barn med depresjon enten ha en forhøyet terskel til å oppleve en positiv affekt, ha en mindre klar respons når en positiv affekt oppleves eller ha problemer med å opprettholde den positive affekten i en passende kontekst (19). En nevrobiologisk tilnærming vil på sikt kunne bidra til å kartlegge og spesifisere nærmere hvilke delprosesser i emosjonsreguleringen som er forstyrret i hvilke sykdommer.

\section{Det nevrobiologiske grunnlaget}

Moden emosjonsregulering oppnås først når nøkkelområder i hjernen er ferdig utviklet og samordnet $(9,20)$. Prefrontal cortex, som består av fremre cingulum cortex (anterior cingulate cortex, ACC), orbitoprefrontal, ventromedial og dorsolateral prefrontal cortex, regulerer primære emosjonelle responser som oppstår i limbiske områder, særlig i amygdala (18). Fremre cingulum cortex består av ulike funksjonelle områder som prosesserer emosjonell og kognitiv informasjon og er grunnleggende for kontroll av oppmerksomhet (21). Fremre cingulum cortex har tette forbindelser til dorsolateral prefrontal, parietal og motorisk cortex (dorsal fremre cingulum cortex) og deler samtidig strukturelle og funksjonelle forbindelser med orbitofrontal cortex, amygdala og hippocampus (ventral fremre cingulum cortex). Denne delen av cortex kan dermed anses å formidle mellom forskjellige nettverk i hjernen.

\section{Det emosjonelle nettverket}

Det emosjonelle nettverket (amygdala, hippocampus, ventral striatum og ventral fremre cingulum cortex, ventromedial og orbitofrontal cortex) prosesserer emosjonelle stimuli, genererer emosjonelle responser og danner forventninger om negative og positive utfall av handlinger (22). Dette nettverket er derfor assosiert med tilnærmings- eller belønningssøkende atferd $(16,19)$ og er sentral i sosial kommunikasjon og læring (23).

\section{Det kognitive nettverket}

Det kognitive nettverket omfatter dorsale frontale regioner, slik som dorsal fremre cingulum cortex og dorsal striatum og er avgjørende for atferds- og emosjonsregulering $(6,8)$. Disse hjerneområdene modnes sent (i ungdomsalderen) og langsomt $(8,14)$. Områdene bidrar til å kontrollere upassende og automatisk atferd og fører til mer rasjonell og fleksibel beslutningstaking. Evnen til å bryte en vane og forsøke en ukjent, men mer sosialt passende atferd, blir også assosiert med dette nettverket (5).
Hjernen i vekst

Det emosjonelle og det kognitive nettverket modnes mens hjernen gjennomgår betydelige strukturelle endringer i oppvekst. Det er relevant å kjenne til grunntrekkene i utviklingen, som styres av samspill mellom miljøpåvirkninger og genetisk/biologiske faktorer (fig 1) $(24,25)$ : Hjernens grå substans (som hovedsakelig består av nevronene) følger et omvendt U-formet utviklingsløp gjennom barndom og ungdomsalder, først vekst og deretter tap av masse. Hvit substans (hovedsakelig myelin) viser derimot en lineær økning i tykkelse fra barn til voksen.

Kortikal tykkelse øker i fosterlivet og i tidlig barndom og når toppen i skolealderen. Tykkelsen av cortex, som kan måles ved anatomiske MR-undersøkelser, er et resultat av mengden nevroner og synapser. Skulpturering og modning av hjernen består hovedsakelig av en overproduksjon av nevroner i fosterlivet og barndommen, fulgt av en periode med programmert celledød i perinatal periode og tidlig barndom, mens aktivitetsavhengig eliminasjon av synapser er et hovedtrekk i ungdomstiden $(26,27)$. Synapser som ikke blir brukt, skjæres ned, mens synapser som brukes ofte, styrkes.

Parallelt til den dynamiske utvikling av grå substans vokser også hvit substans. Denne veksten er assosiert med myelinisering, som fører til raskere nevral impulsoverføring og bidrar indirekte til at cortex blir tynnere. Grå substans i områder som blir mye brukt, tynnes tilsynelatende ut når nevronene blir myelinisert (26). Hvor raskt den hvite substansen vokser, avhenger av alder og miljøpåvirkning. Myelinisering fører til en mer effektiv og finjustert informasjonsprosessering og danner grunnlag for $ø$ kt forbinding i hjernen (28). Studier med funksjonell MR eller EEG-koherens-studier, bekrefter at samhandlingen mellom de enkelte hjerneområdene og danning av ulike nettverk øker i takt med emosjonell og kognitiv utvikling (29).

\section{Diskontinuerlig utvikling}

Ungdom opptrer ofte mer umodent enn prepubertale barn, noe som kan ses i sammenheng med en ulik modningsgrad av nettverkene i hjernen. Deler av det emosjonelle nettverket modnes tidlig, sammenliknet med det kognitive kontrollnettverket i frontallappen. Dette kan være med på å forklare hvorfor barn og unge lærer å regulere følelsene sine heller skrittvis enn kontinuerlig $(6,9$, 19). Funksjonell MR-studier viser at ungdommer som forventer en belønning, aktiverer nucleus accumbens i større grad enn barn. Samtidig er aktiveringen i orbitofrontal cortex mer diffus hos ungdommer enn hos voksne $(14,30)$. Denne ubalansen i modningsgrad av ulike deler av hjernen kan forklare ungdoms tilbøyelighet til risikofylt atferd. Det kan også forklare at ungdom ofte er i stand til å ta fornuftige beslutninger når følelsene ikke er satt i sving, men har større problemer med beslutningstaking under intense emosjonelle forhold (8). Ungdommens vilje til å våge seg ut i ukjent terreng var mer hensiktsmessig i gamle dager da det var vanlig å forlate hjemmet tidlig, men i våre dager fører den heller til uønsket risikoatferd (6).

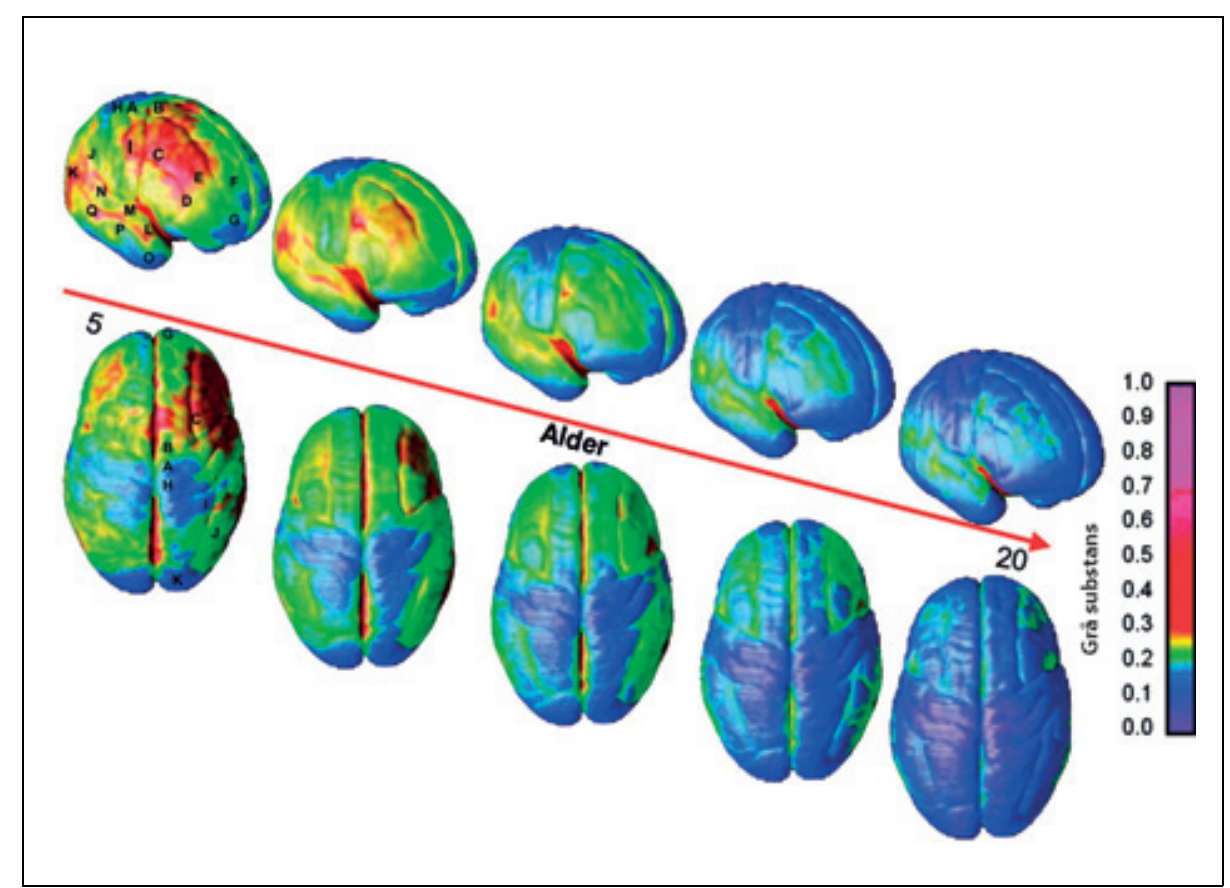

Figur 1 Dynamiske forandringer av kortikal grå substans. Søylen til høyre viser volum av grå substans. I frontallappen når grå substans toppen i 9,5-årsalder hos jenter og 10,5-årsalder hos gutter, temporallappen ved tiårsalder hos jenter og 11 - årsalder hos gutter, i parietallappen i 7,5-årsalder hos jenter og niårsalder hos gutter (24, 28). Gjengitt fra Gogtay og medarbeidere (25). @ 2004 The National Academy of Sciences of the United States of America 


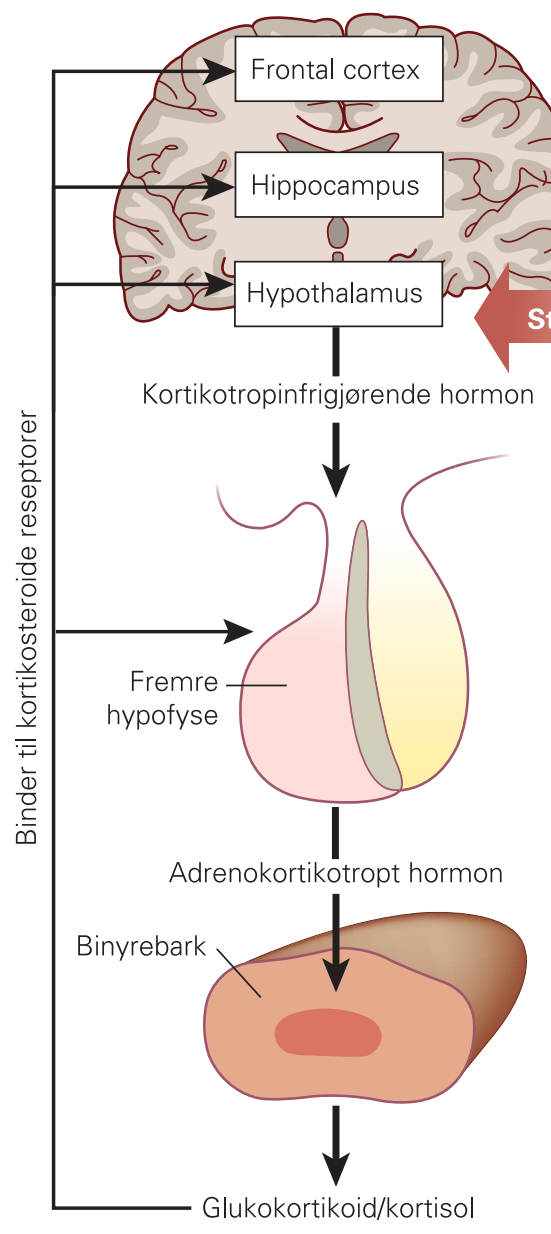

\section{Faktorer for utvikling av emosjonsregulering}

Emosjonell utvikling er et resultat av samspill mellom arv og miljø. Hvordan de miljømessige risikofaktorene påvirker oss, er avhengig av vår genetiske utrustning (31). Genene kan skape både sårbarhet og beskyttelse for miljømessige forhold (18). Problemer med emosjonell regulering kan imidlertid også opptre uten at det foreligger noe form for negativ miljøpåvirkning. Dette er blitt beskrevet eksempelvis i forhold til utvikling av angst, der man har funnet en sterk biologisk markør (endofenotype), som beskrives som en forsterket oppmerksomhet overfor truende stimuli (18).

Vi har valgt å belyse to miljøfaktorer som er særlig relevante for utvikling av emosjonell regulering - og som også egner seg for forebyggende tiltak.

\section{Interaksjon mellom barn og foreldre}

Tilknytning er et typisk eksempel på ytre regulering av følelser som er nødvendig for at barnet i oppveksten kan utvikle kontroll over egne følelser. Foreldrenes fysiske og psykiske nærhet og oppmerksomhet er utgangspunktet for at barnet skal lære å «lese» ulike situasjoner og sosiale koder (32). Trygg tilknytning danner grunnlaget for nevrobio- logisk organisering av perseptuelle, emosjonelle og relasjonelle forhold $(10,33,34)$. I studier der det er brukt funksjonell MR, er det hittil bare undersøkt hvordan foreldrenes hjerne blir aktivert på signaler som barnet sender ut. Foreldrene aktiverer cingulum cortex med tilbakekoblingssløyfer til midthjerne, basalgangliene og thalamus for motivasjon og belønning (34). Det ville også være relevant å kartlegge eksempelvis ved hjelp av funksjonell MR-undersøkelser hvordan hjernen til barnet aktiveres når barnet forholder seg til en trygg foreldreperson. Det gjenstår også å gjennomføre slike studier hos barn og foreldre samtidig.

\section{Misbruk, vold og forsømmelse i barndommen}

Barns nevrale nettverk er spesielt sårbart for forstyrrende miljøeffekter fordi nervesystemet er spesielt plastisk under utviklingen (17). Langvaring eksponering for mishandling og forsømmelse påvirker hjernens kjemiske og hormonelle balanse (dysregulering av hypothalamus-hypofyse-binyrebarkaksen (HPA-aksen)) (fig 2) (35) og kan resultere i psykisk og fysisk stress. Dyremodeller viser at en dysregulering av HPA-aksen korrelerer med degenerering av hippocampus og frontale hjerneområder (36).
Dette påvirker eliminasjon av synapser i områder som er avgjørende for en vellykket tilpasning $(36,37)$. Misbruk, vold og forsømmelse svekker evnen til å regulere emosjoner, noe som kan føre til aggresjon, vold og mangel på sosiale relasjoner senere i livet (38). Den direkte biologiske påvirkningen gjennom forhøyet kortisol på limbiske områder har imidlertid bare blitt påvist $\mathrm{i}$ dyrestudier, og det står fremdeles igjen å påvise mekanismer som medierer slike effekter hos barn. En mindre hippocampus predisponerer for utvikling av posttraumatisk stressforstyrrelse hos voksne (39), mens barn med samme tilstand som følge av misbruk viser ingen konsistent reduksjon av volum i hippocampus (40) (fig 2).

\section{Konklusjon}

Barne- og ungdomsalderen er en kritisk periode for hjerneutvikling. I fremtiden kan kunnskap om hjernens utvikling forhåpentligvis danne grunnlaget for utvikling av mer kunnskapsbaserte terapimetoder i barne-og ungdomspsykiatrien. Klinisk forskning bør utvikle eksperimentelle metoder (ved funksjonell MR eller ved EEG/ERP (event related potentials)-undersøkelser) som er tilpasset situasjoner fra det virkelige livet, for at denne kunnskapen kan komme pasientene til gode. Longitudinelle studier der man undersøker utviklingen hos de samme barna over tid vil også være spesielt viktig. Translasjonelle studier, der man legger sammen informasjon om genetikk, ulike oppvekstfaktorer og nåværende symptomer med eksempelvis funksjonell MR-undersøkelser, vil på sikt kunne identifisere positive faktorer og risikofaktorer for en avvikende emosjonsregulering hos enkelte grupper av barn. Dette vil også kunne bidra til å definere grupper av barn som kan være spesielt utsatt og barn som kan profittere på spesielle terapeutiske tilnærminger og forebyggende tiltak.

Forfatterne har fått støtte fra Samarbeidsorganet Helse-Vest (Mood-net), Nasjonal Forskningsnettverk AD/HD (Kerstin Plessen) og fra Regionsenter for barn og unges psykiske Helse-Vest IGalina Kabicheva), Unifob Helse til å skrive manus. Vi takker Marie Farstad Høvik for språklig gjennomgang og Kenneth Hugdahl for kommentarer til en tidligere versjon av manuskriptet.

Oppgitte interessekonflikter: Ingen

\section{Litteratur}

1. Nigg JT, Casey BJ. An intergrative theory of attention-deficit/hyperactivity disorder based on the cognitive and affective neurosciences. Dev Psychopathol 2005; 17: 785-806

2. Webster-Stratton C. De utrolige årene: en veiledning i problemløsning for foreldre med barn i alderen 2-8 år. Oslo: Gyldendal Akademisk, 2007.

3. Gevensleben H, Holl B, Albrecht B et al. Is neurofeedback an efficacious treatment for ADHD? A randomised controlled clinical trial. J Child Psychol Psychiatry 2009; 50: 780-9. 
4. Berger A, Kofman O, Livneh U et al. Multidisciplinary perspectives on attention and the development of self-regulation. Prog Neurobiol 2007; 82: $256-86$.

5. Bell MA, Deater-Deckard K. Biological systems and the development of self-regulation: integrating behavior, genetics, and psychopsysiology. J Dev Behav Pediatr 2007; 28: 409-20.

6. Casey BJ, Jones RM, Hare TA. The adolescent brain. Ann N Y Acad Sci 2008; 1124: 111-26.

7. Kerr A, Zelazo PD. Development of «hot» executive function: the children's gambling task. Brain Cogn 2004; 55: 148-57.

8. Steinberg L. Cognitive and affective development in adolescence. Trends Cogn Sci 2005; 9: 69-74.

9. Dahl RE. Adolescent brain development: a period of vulnerabilities and opportunities. Ann N Y Acad Sci 2004: 1021: 1-22.

10. Posner MI. Genes and experience shape brain networks of conscious control. Prog Brain Res 2005; 150: 173-83.

11. Gross JJ, Thompson RA. Emotion regulation: conceptual foundation. I: Gross JJ, red. Handbook of emotion regulation. New York, NY: The Guilford Press, 2007

12. de Sousa R. Emotion. I: Zalta EN, red. Stanford encyclopedia of Philosophy. Stanford, CA: The Metaphysics Research Lab, Center for the Study of Language and Information, Stanford University, 2007.

13. Gerber AJ, Posner J, Gorman D et al. An affective circumplex model of neural systems subserving valence, arousal, and cognitive overlay during the appraisal of emotional faces. Neuropsychologia 2008; 46: 2129-39

14. Galvan A, Hare TA, Parra CE et al. Earlier development of the accumbens relative to orbitofrontal cortex might underlie risk-taking behavior in adolescents. J Neurosci 2006; 26: 6885-92.

15. Calkins SD, Fox NA. Self-regulatory prosesses in early personality development: a multilevel approach to the study of childhood social with drawal and aggression. Dev Psychopathol 2002; 14: 477-98.

16. Lewis MD, Granic I, Lamm C. Behavioral differences in aggressive children linked with neural mechanisms of emotion regulation. Ann N Y Acad Sci 2006; 1094: 178-92.
17. Gross C. Hen R. The developmental origins of anxiety. Nat Rev Neurosci 2004; 5: 545-52.

18. Lau JY, Pine DS. Elucidating risk mechanisms of gene-environment interactions on pediatric anxiety: intregrating findings from neuroscience. Eur Arch Psychiatry Clin Neurosci 2008; 258: 97-106

19. Forbes EE, Dahl RE. Neural systems of positive affect: relvance to understanding child and adolescent depression? Dev Psychopathol 2005; 17: $827-50$.

20. Davidson RJ, Putnam KM, Larson CL. Dysfunction in the neural circuitry of emotion regulation a possible prelude to violence. Science 2000; 289 : $591-4$

21. Bush G, Luu P, Posner MI. Cognitive and emotional influences in anterior cingulate cortex. Trends Cogn Sci 2000; 4: 215-22.

22. Herba C. Phillips M. Annotation: Development of facial expression recognition from childhood to adolescence: behavioural and neurological perspectives. J Child Psychol Psychiatry 2004; 45: $1185-98$.

23. Grossmann T, Johnson MH. The development of the social brain in human infancy. Eur $\mathrm{J}$ Neurosci 2007; 25: 909-19.

24. Rapoport JL, Gogtay N. Brain neuroplasticity in healthy, hyperactive and psychotic children insights from neuroimaging. Neuropsychopharmacology 2008; 33: 181-97.

25. Gogtay N, Giedd JN, Lusk L et al. Dynamic mapping of human cortical development during childhood through early adulthood. Proc Natl Acad Sci U S A 2004; 101: 8174-9.

26. Marsh R, Gerber AJ, Peterson BS. Neuroimaging studies of normal brain development and their relevance for understanding childhood neuropsychiatric disorders. J Am Acad Child Adolesc Psychiatry 2008; 47: 1233-51.

27. Sowell ER, Thompson PM, Leonard CM et al. Longitudinal mapping of cortical thickness and brain growth in normal children. J Neurosci 2004; 24: $8223-31$

28. Giedd JN. The teen brain: insights from neuroimaging. J Adolesc Health 2008; 42: 335-43.

29. Stevens MC. The developmental cognitive neuroscience of functional connectivity. Brain Cogn 2009; 70: 1-12
30. Yrgelun-Todd D. Emotional and cognitive changes during adolescence. Curr Opin Neurobiol 2007; 17 $251-7$.

31. Wallace GL, Eric Schmitt J, Lenroot R et al. A pediatric twin study of brain morphometry. J Child Psychol Psychiatry 2006; 47: 987-93.

32. Feldman R. Parent-infant synchrony and the contruction of shared timing; psysiological precursors, developmental outcomes, and risk conditions. J Child Psychol Psychiatry 2007; 48: 329-54

33. Fonagy $P$, Gergely $G$, Target $M$. The parent-infant dyad and the construction of the subjective self. J Child Psychol Psychiatry 2007; 48: 288-328.

34. Swain JE, Loberbaum JP, Kose $\mathrm{S}$ et al. Brain basis of the early parent-infant interactions: psychology, physiology, and in vivo functional neuroimaging studies. J Child Psychol Psychiatry 2007; 48: 262-87.

35. McEwen BS. Early life influences on life-long patterns of behavior and health. Ment Retard Dev Disabil Res Rev 2003; 9: 149-54.

36. Compas BE. Psychobiological processes of stress and coping: implication for resilience in children and adolescents - comments on the paper of Romeo \& McEwen and Fisher et al. Ann N Y Acad Sci 2006; 1094: 226-34

37. Glaser D. Child abuse and neglect and the brain a review. J Child Psychol Psychiatry 2000; 41: 97-116.

38. Lee V, Hoaken PN. Cognition, emotion, and neurobiological development: mediating the relation between maltreatment and aggression. Child Maltreat 2007: 12: 281 - 98

39. Gilbertson MW, Shenton ME, Ciszewski A et al. Smaller hippocampal volume predicts pathologic vulnerability to psychological trauma. Nat Neurosci 2002; 5: 1242-7.

40. Woon FL, Hedges DW. Hippocampal and amygdala volumes in children and adults with childhood maltreatment-related posttraumatic stress disorder: a meta-analysis. Hippocampus 2008; 18: 729-36.

Manuskriptet ble mottatt 18.2. 2009 og godkjent 4.2. 2010. Medisinsk redaktør Trine B. Haugen. 